\title{
DIAMOND-BEARING ALKALINE INTRUSIONS FROM WANDAGEE, CARNARVON BASIN, WESTERN AUSTRALIA
} \author{
I.D. Kerr ${ }^{4}$, A.L. Jaques
and B.W. H. Lhappellas
}

1. CRA Exploration Pty Ltd, P.0. Box 175, Belmont, WA 6104.

2. Bureau of Mineral Resources, GPO Box 378, Canberra, ACT 2601.

3. Geology Dept, Australian National University, Canberra, ACT 2600 .

4. 182 Mica St, Broken Hill, New South Wales, 2880.

Reconnaissance stream-sediment sampling and aeromagnetic surveys led to the discovery in 1978 by CRA Exploration Pty Ltd of 16 small kimberlite-like diatremes and associated sills and dykes in the vicinity of Wandagee Hill in the northern Carnarvon Basin of Western Australia (Atkinson et al 1984; Jaques et al 1986). Subsequent exploration by Stockdale Prospecting Ltd located an additional diatreme and a number of sills and dykes. A total of 22 bodies, 14 diatremes and 8 sills and dykes, are now known from the Wandagee area where they form an elongate $\mathrm{N}-\mathrm{S}$ belt some $50 \mathrm{~km}$ long and $15 \mathrm{~km}$ wide at the eastern margin of the Wandagee Ridge, a basement horst which separates the Merlinleigh sub-basin to the east from the onlapping Gasgoyne sub-basin to the west. The Merlinleigh sub-basin, a half-graben filled with up to $6 \mathrm{~km}$ of mainly Permian sediments, forms part of the Carnarvon Basin which is a Phanerozoic trough infilled with terrestrial and marine clastic sediments and developed at the western margin of the continent prior to breakup of Gondwanaland (Veevers,1981). The Wandagee bodies intrude Permian (Artinskian) black shales and siltstones. U-Pb dating of zircon indicates a Jurassic $(160 \pm 10 \mathrm{Ma})$ age of emplacement (Atkinson et al 1984; Pidgeon et al, this volume) which is consistent with stratigraphic relations and coincides with the early rift phase of the breakup. The diatremes range in size from 1 to $14 \mathrm{ha}$ and are covered by up to $160 \mathrm{~m}$ of late Cretaceous (Aptian) sediments and Recent deposits. They are steep-side, pipe-shaped bodies filled with decomposed tuffs and tuff-breccias which locally are weakly bedded. The Wandagee tuffs are therefore assigned to the lower part of the crater zone in the kimberlite pipe model of Hawthorn (1975). The sill and dykes range in thickess from 1 to $15 \mathrm{~m}$, and are composed of dark, massive, porphyritic picrite.

\section{PETROLOGY}

The sills and dykes are highly porphyritic picrites containing abundant olivine phenocrysts and microphenocrysts $\left(\mathrm{Mg}_{92-87}\right)$, subordinate olivine macrocrysts ( $\mathrm{Mg}_{92-90}$ ) and diopside micophenocrysts set in a groundmass crowded with a felt-like mass of I1Al salite prisms and granular spinel. The largely cryptocrystalline, interstitial base is composed mainly of Al-rich serpentine but alkali feldspar is discernable in places and apatite is present in coarser grained rocks. Also present, particularly in abundant segregation, vesicles and veinlets filled with calcite is analcime, mauve titansalite, biotite, kaersutite, and skeletal Ti-magnetite. The pyroxenes and spinels exhibit a wide range of compositions. The pyroxenes range from diopside cores with low $\mathrm{TiO}_{2}(<0.7 \mathrm{wt} \%), \mathrm{Al}_{2} \mathrm{O}_{3}(1-2$ wt $\%)$ and $\mathrm{Na}_{2} \mathrm{O}\left(0.2-0.3\right.$ wt \%) and moderate $\mathrm{Cr}_{2} \mathrm{O}_{3}$ (up to 1 wt \%) to rims of $\mathrm{T}_{1}^{2}{ }^{3}$ and Al-rich salite (up to 3 wt \% $\mathrm{TiO}_{2}$, 8 wt \% $\mathrm{Al}_{2}^{2} \mathrm{O}_{3}^{3}$ ) with higher $\mathrm{Na}$ (up to 0.9 wt $\% \mathrm{Na}, 0$ ) and negiligible $\mathrm{Cr}$. The mauve brown variolitic pyroxenes in the segregation patches extend to more $\mathrm{Ti}$ - and Al-rich compositions (up to 5 wt $\% \mathrm{TiO}_{2}$ and 11 wt $\% \mathrm{Al}_{2} \mathrm{O}_{3}$ ). The spinel compositions range from titaniferous aluminous chromite (TMAC) with up to $60 \% \mathrm{Cr}_{2} \mathrm{O}_{3}$ through $\mathrm{Mg}$-poor titaniferous chromite (TC) and titaniferous chromian magnetite 2 (TCM) to titaniferous magnetite (TM) containing up to 19 wt $\% \mathrm{TiO}_{2}$. Individual grains are typically zoned from TMAC and TMC cores to TCM and TM rims.

The highly altered tuffs are composed of juvenile lapilli and coarse ash together with accidental lithic fragments, particularly pyritic shale. The juvenile clasts which are commonly cored by altered olivine, $0.5-5 \mathrm{~mm}$ across, or less commonly phlogopites, consist of phenocrysts and micro-phenocrysts of former olivine and magnesian Al-rich phlogopite in an altered groundmass of serpentine and carbonate containing sub- to euhedral spinels. The spinels in the tuffs also exhibit a wide 
range of compositions from ${ }_{3} \mathrm{Cr}$ and $\mathrm{Al}-\mathrm{rich}$ types (TMAC with up to $50 \mathrm{wt} \% \mathrm{TiO}_{2}$ and 16 wt $\% \mathrm{Al}_{2} \mathrm{O}_{3}$ ) towards more $\mathrm{Fe}^{3+}$ - and $\mathrm{Ti}$-rich compositions i.e. aluminous TC and ${ }^{2} \mathrm{TCM}$ and TM with up to 15 wt $\% \mathrm{TiO}_{2}$. Compared to the spinels in the picrite dykes and sills those in the tuffs are richer in $\mathrm{Mg}$ and $\mathrm{Al}$ and, thus more like spinels found in kimberlite (Haggerty 1976).

Concentrates from the Wandagee bodies have yielded magnesio-chromite, chrome diopside, garnet, picroilmenite, olivine, kimberlitic mica and zircon, and extremely rare diamond. The chromites are rich in $\mathrm{Mg}$ and $\mathrm{Cr}(\mathrm{Cr} /(\mathrm{Cr}+\mathrm{Al})=0.7-0.77)$, and have high $\mathrm{TiO}_{2}$ contents (up to 5 wt \%). The chrome diopsides are rich in $\mathrm{Ca}$, poor in $\mathrm{Al}, \mathrm{Na}$, and $\mathrm{Ti}$, and contain up to $2 \mathrm{wt} \% \mathrm{Cr}_{2} \mathrm{O}_{3}$. The garnets belong mainly to Dawson and Stephens (1975) cluster groups 1, 9, and 11 and, with rare exception, fall well within the Ca-rich field on $\mathrm{CaO}_{-} \mathrm{Cr}_{2} \mathrm{O}_{3}$ diagrams (Gurney 1984) discriminating garnets from lherzolite and garnets from diamond inclusions. The picroilmenite has moderate to high MgO contents $(8-20$ wt \%).

Microxenoliths of dunite with coarse or granular texture are common. Also present are small xenoliths of crustal metamorphics derived from the Precambrian basement including sillimanite, garnet, biotite, feldspar-quartz granulite and hornblendeplagioclase-quartżgarnet granulites.

\section{CHEMISTRY}

The picrites have uniformly high Mg0 contents (21-28\%), are very rich in normative olivine and range from slightly undersaturated to barely saturated. They have low contents of $\mathrm{Na}_{2} \mathrm{O}$ and $\mathrm{K}_{2} \mathrm{O}$ (av. 1 wt \%) with $\mathrm{Na}_{2} \mathrm{O} / \mathrm{K}_{2} \mathrm{O}$ ratios ratios near 1 . The picrites have comparatively low levels of enrichment in incompatible elements; $\mathrm{Ba}=$ 200-800 ppm, $\mathrm{Rb}=10-30 \mathrm{ppm}, \mathrm{Sr}=100-600 \mathrm{ppm}, \mathrm{Zr}=75-200 \mathrm{ppm}, \quad \mathrm{Nb}=30-60 \mathrm{ppm}$, $\mathrm{Ta}$ and $\mathrm{Hf}=2-3 \mathrm{ppm}$. They have moderate $\mathrm{K} / \mathrm{Rb}(200-300)$ ratios and low $\mathrm{Rb} / \mathrm{Sr}$ ( $\mathrm{av}$. $0.05)$, Th/U (3-4), and $\mathrm{Zr} / \mathrm{Nb}$ (2-3) ratios. The Wandagee picrites have strongly fractionated REE patterns with LREE enrichments of 90-120x chondrites and low abundances of HREE (3-4x). Similar abundances of LREE are found in both kimberlite and highly undersaturated basalts but the very low abundances of HREE is more typical of kimberlite (Fesq et al 1975; Nixon et al 1981). Sr and Nd isotope data indicate that the picrites have been derived from mantle with $\mathrm{Nd}$ and $\mathrm{Sr}$ isotopic ratios close to 'bulk earth'.

Chemical data on the tuffs is hindered by their fragmental nature and highly altered state. Analyses of the groundmass in the juvenile clasts by microprobe using a defocussed beam gave compositions broadly similar to, although less $\mathrm{Mg}-\mathrm{rich}$ than, the picrites (Atkinson et al 1984). This suggests that the Wandagee tuffs might be closer in chemistry to the picrites than is suggested by the differences in their mineralogy and mineral chemistry. An important observation is that neither contain perovskite indicating that they are not strongly silica undersaturated.

\section{DISCUSSION}

The mineralogy and chemistry of the picrites suggest affinities with undersaturated basaltic rocks. The lower abundances of incompatible elements in the Wandagee picrites may be interpreted in terms of larger degrees of partial melting under comparatively shallow depths compared to kimberlites (cf Frey et al 1977). Nd and $\mathrm{Sr}$ isotopic ratios in the Wandagee rocks are similar to those in group I (nonmicaceous) kimberlite (Smith 1983) and unảersaturated basaltic rocks whose generation is believed to include involvement of the convecting mantle (e.g. McDonough et al, 1985). The microxenoliths and the nature of the xenocryst garnets and pyroxenes indicate the presence of depleted garnet lherzolite beneath the Wandagee region. The presence of rare diamond indicates that at least some of the Wandagee pipes have tapped mantle within the diamond stability field. The Wandagee rocks therefore add to the spectrum of volcanic rocks now known to host diamond. However, the rarity of diamond in the Wandagee intrusives suggest that they are largely derived from depths above the diamond stability field and are therefore unlikely to host diamond at economic grades. The Wandagee intrusions are interpreted as having been derived by small to moderate degrees of partial melting, involving interaction of depleted, refractory lherzolite of the subcontinental lithosphere with diapiric mantle derived from the convecting asthenosphere. This model is similar to the models of Nixon et al 
(1981) for kimberlites and McDonough et al (1986) for alkali basalts. The upwelling of the asthenosphere is inferred to have been generated in response to rifting processes associated with the break up of Gondwanaland.

\section{ACKNOWLEDGEMENTS}

We thank CRA Exploration Pty Ltd for permission to publish, and C.B. Smith for his help in initiating the study. ALJ and S-S.S publish with the permission of the Director, Bureau of Mineral Resources.

\section{REFERENCES}

ATKINSON W.J., HUGHES F.E. and SMITH C.B. 1984. A review of the kimberlitic rocks of Western Australia. In Kornprobst J. ed, Kimberlites 1: Kimberlites and Related Rocks, pp. 195-224. Elsevier, Amsterdam.

FESQ H.W., KABLE E.J.D. and GURNEY J.J. 1975. Aspects of the geochemistry of kimberlites from the Premier mine and other selected South African occurrences with particular reference to the rare earth elements. Physics and Chemistry of the Earth 9, 687-709.

FREY F.A., FERGUSON J. and CHAPPELL B.W. 1977. Petrogenesis of South African and Australian kimberlite suites. (Abstract). Second International Kimberlite Conference, Santa $\mathrm{Fe}$ (unpaged).

HAGGERTY S.E. 1976. Opaque mineral oxides in terrestrial igneous rocks. In Rumble D. ed, Reviews in Mineralogy - Volume 3, Oxide Minerals, pp. 101-300. Mineralogical Society of America.

HAWTHORNE J.B. 1975. Model of a kimberlite pipe. Physics and Chemistry of the Earth 9 , $1-15$.

GURNEY J.J. 1984. A correlation between garnets and diamonds in kimberlites. In Glover J.E. and Harris P.G. eds, Kimberlite Occurrence and Origin, pp. 143-166. Geology Department and Extension, University of Western Australia, Publication No 8.

JAQUES A.L., LEWIS J.D. and SMITH C.B. 1986. The kimberlitic and lamproitic rocks of Western Australia. Geological Survey of Western Australia Bulletin 132.

MCDONOUGH W.F., MCCULLOCH M.T. and SUN S-S. 1985. Isotopic and geochemical systematics in Tertiary-Recent basalts from southeastern Australia and implications for the evolution of the sub-continental lithosphere. Geochimica et Cosmochimica Acta 49, 2051-2067.

NIXON P.H., ROGERS, N.W., GIBSON I.L. and GREY A. 1981. Depleted and fertile mantle xenoliths from southern African kimberlites. Annual Reviews of Earth and Planetary Sciences 9, 285-309.

SMITH C.B. 1983. $\mathrm{Pb}, \mathrm{Sr}$ and $\mathrm{Nd}$ isotope evidence for sources of southern African Cretaceous kimberlite. Nature 304, 51-54.

VEEVERS J.J. 1981. Morphotectonics of rifted continental margins in embryo (East Africa), youth (Africa-Arabia) and maturity (Australia). Journal of Geology 89, 57-82. 